\title{
Isolation of hexavalent chromium (vi) tolerant fungi from tannery effluent and their growth responses to different concentrations of chromium ( $v i$ )
}

\section{Aislamiento de hongos tolerantes de cromo hexavalente (vi) de los efluentes de Tannery y sus respuestas de crecimiento a las diferentes concentraciones de cromo (vi)}

\author{
Soumyajit Guha, Sampa Debnath and Saswati Gayen*
}

\begin{abstract}
Department Of Microbiology, Vijaygarh Jyotish Ray College, Kolkata - 700032, West Bengal, India.
\end{abstract}

*Corresponding author, Assistant Professor, E-mail: saswatimicrobio@gmail.com

Research Scholar, E-mail: soumyajitguhas42@gmail.com

\begin{abstract}
The main objective of this study was to isolate, characterize, and determine chromium (VI) tolerance capacities of fungal strains from tannery effluent of Kolkata Leather Complex area. Chromium (VI) is a heavy metal that is known to be toxic as well as carcinogenic. It is an important heavy metal widely used in various industries of which the tanning industry deserves special mention. The majority of $\mathrm{Cr}(\mathrm{VI})$ waste is discharged into the environment annually as a consequence of industrial and manufacturing activities. Kolkata Leather Complex is an industrial complex intended to serve as a central leather-tanning complex for Kolkata located at Bantala, near East Kolkata, India. Samples (tannery effluent) were collected in sterile capped tubes from Kolkata Leather Complex Area and brought to the laboratory for analysis. The samples were serially diluted and were plated on Czapekdox agar plates and incubated at $30^{\circ} \mathrm{C}$. After a few days, a number of morphologically different colonies were selected and sequentially subcultured for pure colony isolation on the same medium. They were preserved in the refrigerator at $4^{\circ} \mathrm{C}$. Lactophenol cotton blue staining was done to observe and record the fungal morphological characteristics. They were further assessed for their hexavalent chromium tolerance capacities and subsequently the metal tolerance index was derived for each strain respectively. All 16 fungal strains isolated from the Kolkata Leather Complex tannery area were found to be chromium (VI) tolerant starting at $0.1 \mathrm{mg} / \mathrm{ml} \mathrm{Cr}(\mathrm{VI})$ concentration. Maximum chromium (VI) tolerance was displayed by sample S12 $(2 \mathrm{mg} / \mathrm{ml})$ which was later identified as having $99.82 \%$ similarity with Aspergillus nomius strain.
\end{abstract}

Keywords: effluent, fungi, heavy metal, isolation, hexavalent chromium, tannery, tolerance. 


\section{RESUMEN}

El objetivo principal de este estudio fue aislar, caracterizar y determinar las capacidades de tolerancia al cromo (VI) de las cepas de hongos del efluente de la curtiduría del área del complejo de cuero de Kolkata. El cromo (VI) es un metal pesado que se sabe que es tóxico y cancerígeno. Es un metal pesado importante ampliamente utilizado en diversas industrias de las cuales la industria del curtido merece una mención especial. La mayoría de los residuos de $\mathrm{Cr}$ (VI) se descargan al medio ambiente anualmente como consecuencia de las actividades industriales y de fabricación. Kolkata Leather Complex es un complejo industrial destinado a servir como un complejo central de curtido de cuero para Kolkata ubicado en Bantala, cerca de East Kolkata, India. Se recogieron muestras (efluente de la curtiduría) en tubos tapados estériles del área del complejo de cuero de Kolkata y se llevaron al laboratorio para su análisis. Las muestras se diluyeron en serie y se sembraron en placas de agar Czapekdox y se incubaron a $30^{\circ} \mathrm{C}$. Después de unos días, se seleccionaron varias colonias morfológicamente diferentes y se subcultivaron secuencialmente para aislamiento puro de colonias en el mismo medio. Se conservaron en el refrigerador a $40^{\circ} \mathrm{C}$. Se realizó una tinción con azul de algodón de lactofenol para observar y registrar las características morfológicas fúngicas. Posteriormente se evaluaron sus capacidades de tolerancia al cromo hexavalente y, posteriormente, se obtuvo el índice de tolerancia al metal para cada cepa respectivamente. Se descubrió que las 16 cepas de hongos aisladas del área de curtiduría del complejo de cuero de Kolkata eran tolerantes al cromo (VI) a partir de una concentración de $\mathrm{Cr}$ (VI) de $0.1 \mathrm{mg} / \mathrm{ml}$. La máxima muestra de tolerancia al cromo (VI) se mostró en la muestra S12 (2 $\mathrm{mg} / \mathrm{ml}$ ) que luego se identificó con una similitud del 99.82\% con la cepa Aspergillus nomius.

Palabras clave: efluentes, hongos, metales pesados, aislamiento, cromo hexavalente, curtiduría, tolerancia.

\section{INTRODUCTION}

The soil and water are frequently contaminated with toxic heavy metals and organic pollutants as an out-turn of human activities (Siddiquee et al. 2015). Heavy metal like Chromium ( $\mathrm{Cr}$ ) is used in an array of different industrial processes like in steel production, wood preservation, leather tanning, aluminum productions, nuclear power production, metal processing, electroplating, iron sheet cleaning, chrome plating, wood preservation, water cooling, inorganic chemical production, galvanometric, electric, mining industries, battery manufacturing, mine drainage, metal corrosion inhibition, paints and pigments, metal plating, etc. and as a result it is being discharged into the environment through the waste water generated from these processes (Papp 1985, Mishara and Doble 2008, Ranjan et al. 2009, Gupta and Rastogi 2009). Chromium can exist in hexavalent as well as in trivalent forms. However, in its hexavalent form it is very toxic, carcinogenic and mutagenic in humans as well as in animals whereas the trivalent form is less toxic, less soluble and thus a lesser hazard (Philip et al. 1998). Exposure to hexavalent chromium may lead to various adverse health effects including growth inhibition, cancer, organ damage, nervous system damage, and in extreme cases, death (Akpor and Muchiem 2010). The removal of heavy metals is a primary consideration for all environmental protection agencies so the development and application of cost-effective processes for the removal of heavy-metals and the detoxification of metal-contaminated wastewaters is essential to improve the competitiveness of industrial processes and simultaneously minimize the environmental hazards of toxic metal-containing effluents (Volesky and Naja 2007). However, the economic consideration of treatment based 
on volume, concentration of metals, and salinity and characteristics of wastewaters makes it impossible to use conventional technologies such as precipitation and sludge separation, chemical oxidation or reduction, ion exchange, reverse osmosis, cementation, coagulation, flocculation, electrochemical treatment, membrane processes, and evaporation (Ahn et al. 2009, Patrón-Prado et al. 2010). Using microorganisms as biosorbents for heavy metals is an effective alternative to existing methods for toxicity reduction and recovery of valuable metals from industrial effluents, because of its good performance and low cost of biosorbent material (Volesky 1987, Brierley 1990 and Gadd et al. 1988).

Despite the fact that heavy metals are acutely toxic to most microbes, there are metal tolerant strains. Long term exposure to metals favors proliferation of microbes that are tolerant to metals and this has been investigated by assaying habitats exposed to anthropogenic or natural metal contamination over extended period (Hutchinson and Symington 1997). Many fungi have been observed to tolerate and detoxify metals by various mechanisms including extra and intracellular precipitations, valence transformations and active uptake. They usually have a high surface to volume ratio and possess the ability to detoxify metals. These are the reasons for which they are considered as potential alternative to chemical compounds for various remediation purposes of dilute solutions of metals and solid wastes (Magyarosy et al. 2002).

Among the use of chromium in various industries leather or tanning industry deserves special mention where chromium salts are used to convert hides into leather and the waste water generated during this process contains chromium often above the permissible limit of $0.1 \mathrm{mg} / \mathrm{L}$ (Das et al. 2011).

India holds $10^{\text {th }}$ position in the world for its foot-wear production and is one of the major producers of raw-skins and hides. There are over 2500 tanneries in the country and about $80 \%$ of them are engaged in the chrome tanning process (Rajmani et al. 1995). There are nearly 500 tanneries in Bantala and they carry out $22-25 \%$ of all the tanning done in India. It is situated about $14 \mathrm{~km}$ from the central business district of Kolkata and spans an area of about 4.5 square kilometers. The complex is meant to serve as a leather-tanning hub for Kolkata (WBIDC annual report 2009-2010). There are pumping stations which carry the effluent from the different tanneries to a Common Effluent Treatment Plant (CETP). But, many problems and disputes concerning completion of the common effluent treatment plant have caused serious difficulties, with toxic waste polluting adjoining areas and the construction activities of some companies and so there is an enormous pressure on the government from various pollution control bodies to regulate and minimize the amount of chromium released by these tanneries (Das 2008).

The main objective of the present study was to isolate chromium tolerant fungal strains and to determine the metal tolerance capacities of the selected strains and derive their respective metal tolerance index so that in the future their biomass can be used for the biosorption of hexavalent chromium.

\section{MATERIALS \& METHODS}

Sample collection and handling: Samples (tannery effluent) from common discharge canal was collected from Kolkata Leather Complex area. The samples were collected in a sterile capped tube $(50 \mathrm{ml}$ capacity). The tubes were then brought to the laboratory for analysis. The samples were shaken vigorously (approx. 20 times) to obtain a uniform distribution of the organisms before plating. 
Isolation of fungal strains from the effluent: The sample was serially diluted in 5 test tubes and marked as stock, $\left(10^{-1}\right),\left(10^{-2}\right),\left(10^{-3}\right),\left(10^{-4}\right),\left(10^{-5}\right)$. All the samples were plated on Czapekdox agar plates and incubated at $30^{\circ} \mathrm{C}$. After a few days a number of morphologically different colonies were selected and sequentially subcultured for pure colony isolation on the same medium. They were tagged as S1 - S16 and preserved in the refrigerator at $4^{0} \mathrm{C}$ for further analyses.

Lactophenol cotton blue staining: To visualize and record various morphological characteristics of the fungal isolates, Lactophenol cotton blue staining was carried out and observed under low to higher magnification of optical microscope.

Growth responses of the isolated fungal strains against different concentrations of $\mathrm{Cr}$ (VI): To assess and derive chromium tolerance of the isolated fungal strains, agar plug transfer method was followed. In this, agar plug from previously cultured plate was inoculated at the center of a freshly chromium (VI) amended Czapekdox agar plates and incubated at $30^{\circ} \mathrm{C}$. Using standardization formula $\left(\mathrm{V}_{1} \mathrm{~S}_{1}=\mathrm{V}_{2} \mathrm{~S}_{2}\right)$, increasing concentrations of $\mathrm{Cr}(\mathrm{VI})(0.1-2 \mathrm{mg} / \mathrm{ml})$ was prepared aseptically by mixing appropriate amounts of Potassium Dichromate solution (stock) with molten agar. After solidification of the plates they were inoculated with the agar plugs and incubated at $30^{\circ} \mathrm{C}$. The growth of the isolates were recorded regularly after 24 hours (Santhi and Guru 2014). The diameter of the growth and time taken to grow and spread is a measure of the chromium (VI) tolerance by the different isolates. As such the isolates which grew quickly or/and spread far from the center can be inferred as more tolerant to chromium (VI) at the defined conditions.

Heavy metal tolerance index: The Metal Tolerance Index (Ti) was determined as the ratio of the extended radius of the treated colony to that of the untreated colony in the plates grown. $\mathrm{Ti}=\mathrm{Dt} / \mathrm{Du}$, where $\mathrm{Dt}$ is the radial extension $(\mathrm{cm})$ of treated colony and $\mathrm{Du}$ is the radial extension (cm) of untreated colony (Santhi and Guru 2014). The Metal Tolerance Index gives a more clear comparative idea of the heavy metal tolerances displayed by the fungal isolates. All of the experiments were performed in triplicates and the data from it were expressed as mean value \pm SD.

\section{RESULTS \& DISCUSSION}

Colony and morphological characteristics of the isolated fungal strains: Different fungal colonies were observed in all the spread plates at different dilutions, from the sample acquired from Kolkata leather complex tannery area. 16 fungal strains were isolated (presented as S1-S16) employing streak plate method. The pure fungal colonies displayed distinct morphological characteristics. Some isolates were observed to give pigmentations (see Table 1 and Fig.1). The morphological characteristics of the isolated fungal strains were observed and recorded. For this, lactophenol cotton blue staining was carried out and the samples were observed under $400 x$ magnification power of the microscope (see Fig. 2 ). The various recorded observations are depicted in details in Table 1.

Growth responses of the isolated fungal strains against different concentrations of $\mathrm{Cr}$ (VI): The growth responses of the different isolates at different concentrations of chromium were studied in this experiment. The responses of the fungi were dependent on the time of incubation and $\mathrm{Cr}(\mathrm{VI})$ concentrations used. They all were incubated for a maximum of 2 weeks at $30^{\circ} \mathrm{C}$ and the concentrations of $\mathrm{Cr}$ (VI) used were from 0.1 $\mathrm{mg} / \mathrm{ml}$ to $2 \mathrm{mg} / \mathrm{ml}$. The analysis of the results inferred that the isolate $\mathrm{S} 12$ was much 
more adapted to grow in the presence of $\mathrm{Cr}$ (VI) than the other isolates at high $\mathrm{Cr}$ (VI) concentration of $2 \mathrm{mg} / \mathrm{ml}$ (see Table 2 ).

Table 1. Colony and Morphological characteristics of the isolated fungal strains (S1 - S16).

\begin{tabular}{|c|c|c|}
\hline Samples (Bantala) & Colony Characteristics & Morphological Characteristics \\
\hline S1 & $\begin{array}{l}\text { The colony surface is woolly in appearance and } \\
\text { off-white in color. Reverse is off-white. }\end{array}$ & $\begin{array}{l}\text { Septate hyphae, with sterigmata, } \\
\text { conidiophore and conidiospores. }\end{array}$ \\
\hline $\mathrm{S} 2$ & $\begin{array}{l}\text { The colony surface texture is powdery, light } \\
\text { brown in color. Reverse is light brownish. }\end{array}$ & $\begin{array}{l}\text { Septate hyphae, conidiophores are } \\
\text { branched with brush like heads bearing } \\
\text { spores, cluster of sterigmata usually in one } \\
\text { place. }\end{array}$ \\
\hline S3 & $\begin{array}{l}\text { The colony surface texture is powdery light } \\
\text { green in color initially, turns deep green with } \\
\text { conidial production and with white borders. The } \\
\text { reverse is off-white. }\end{array}$ & $\begin{array}{l}\text { Septate hyphae, with sterigmata, } \\
\text { conidiophore and conidiospores. }\end{array}$ \\
\hline S4 & $\begin{array}{l}\text { The colony surface is powdery, light brown in } \\
\text { color. Reverse is light brownish. }\end{array}$ & $\begin{array}{l}\text { Septate hyphae, thin mycelium, with } \\
\text { sterigmata, conidiophore and } \\
\text { conidiospores. }\end{array}$ \\
\hline S5 & $\begin{array}{l}\text { The colony surface is powdery, brown in color. } \\
\text { Reverse is light brownish. }\end{array}$ & $\begin{array}{l}\text { Septate hyphae, with sterigmata, } \\
\text { conidiophore and conidiospores. }\end{array}$ \\
\hline S6 & $\begin{array}{l}\text { The colony surface is smooth then turns } \\
\text { powdery, green in color with conidial } \\
\text { production. Reverse is orange. }\end{array}$ & $\begin{array}{l}\text { Septate hyphae, with sterigmata, } \\
\text { conidiophore and conidiospores. }\end{array}$ \\
\hline S7 & $\begin{array}{l}\text { The colony surface texture is powdery green in } \\
\text { color initially, turns deep green with conidial } \\
\text { production and with white borders. The reverse } \\
\text { is off-white. }\end{array}$ & $\begin{array}{l}\text { Septate hyphae, conidiophores are } \\
\text { branched with brush like heads bearing } \\
\text { spores, cluster of sterigmata usually in one } \\
\text { place. }\end{array}$ \\
\hline S8 & $\begin{array}{l}\text { The colony surface is powdery, green in color. } \\
\text { Reverse is dark. }\end{array}$ & $\begin{array}{l}\text { Septate hyphae, with sterigmata, } \\
\text { conidiophore and conidiospores. }\end{array}$ \\
\hline S9 & $\begin{array}{l}\text { The colony surface is powdery with patch like } \\
\text { growth, green in color. Reverse is white. }\end{array}$ & $\begin{array}{l}\text { Septate hyphae, thin mycelium, } \\
\text { conidiophores are branched with brush like } \\
\text { heads bearing spores, cluster of sterigmata } \\
\text { usually in one place. }\end{array}$ \\
\hline $\mathrm{S} 10$ & $\begin{array}{l}\text { The colony surface is powdery, green in color. } \\
\text { Reverse is off-white. }\end{array}$ & $\begin{array}{l}\text { Septate hyphae, with sterigmata, } \\
\text { conidiophore and conidiospores. }\end{array}$ \\
\hline
\end{tabular}

The colony surface is woolly in appearance and white in color. Reverse is off-white.

The colony surface texture is powdery, white in color initially, turns deep green with conidial production and with white borders. The reverse is off-white.

The colony surface is woolly in appearance and white in color. Reverse is white.

The colony surface is powdery, light brown in color. Reverse is light brownish.

The colony surface texture is powdery, white in color initially, turns deep green with conidial production and with white borders. The reverse is off-white.

The colony surface is powdery with patch like growth, raised center and green in color. Reverse is white. 509

Septate hyphae with thin thread-like mycelium was only observed.

Septate hyphae, with sterigmata, conidiophore and conidiospores.

Septate hyphae with thread-like mycelium was only observed.

Septate hyphae, with sterigmata, conidiophore and conidiospores.

Septate hyphae, thin mycelium, conidiophores are branched with brush like heads bearing spores, cluster of sterigmata usually in one place.

Septate hyphae, conidiophores are branched with brush like heads bearing spores, cluster of sterigmata usually in one place. 


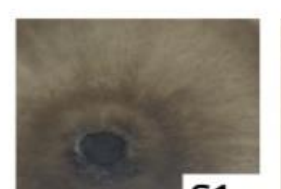

S1

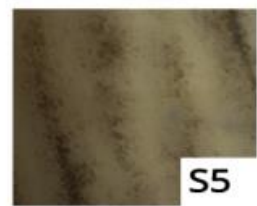

S5
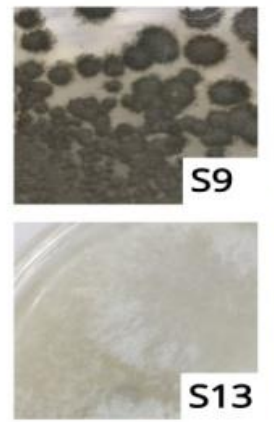
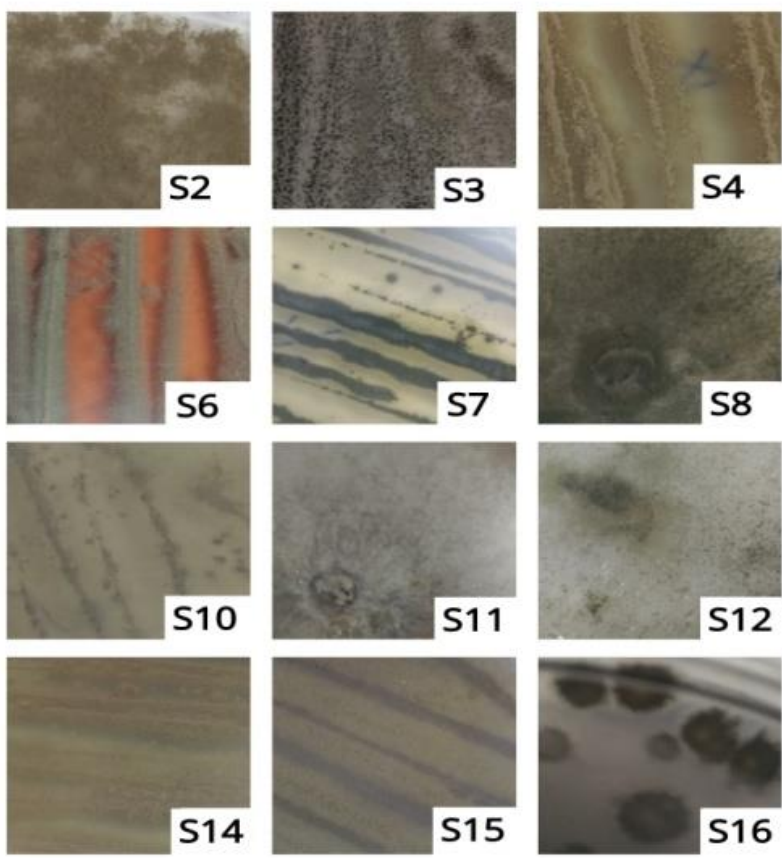

Figure 1 . Colony characteristics of the isolated fungal strains
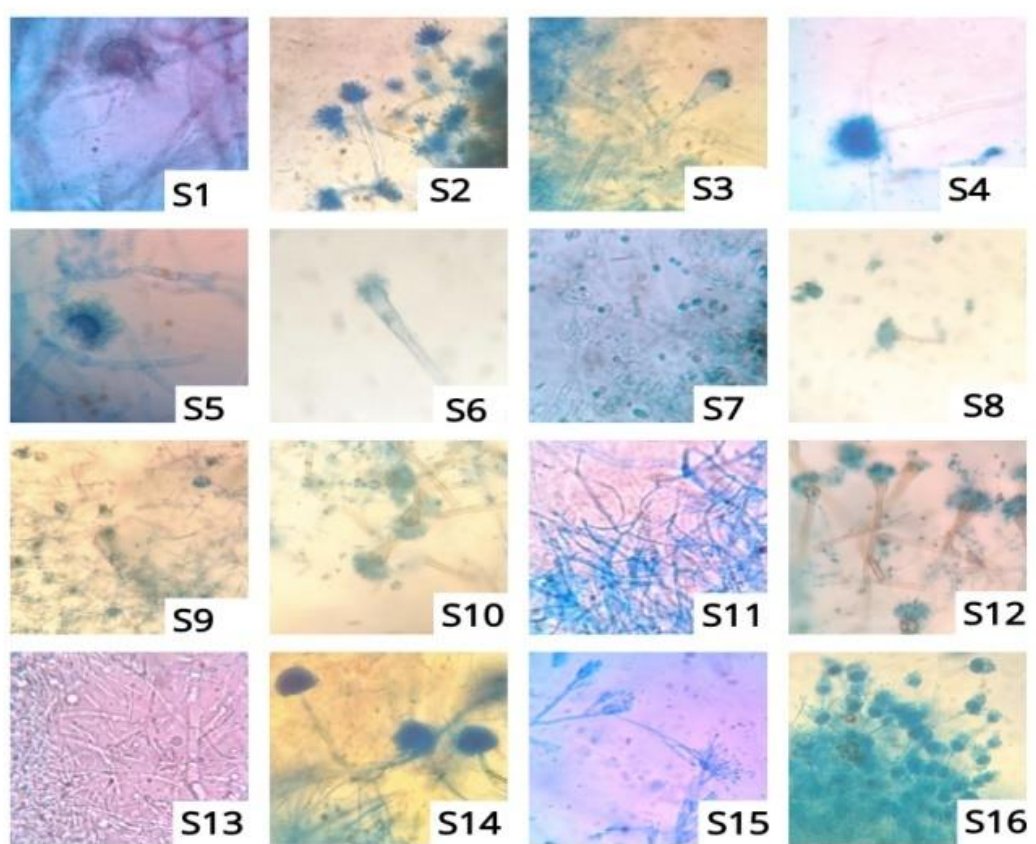

Figure 2. Morphological characteristics of the isolated fungal strains by Lactophenol cotton blue staining - (as observed under 400x magnification power of the microscope) 
Table 2. Growth responses of the isolated fungal strains against different concentrations of chromium (VI)

\begin{tabular}{cc}
\hline Samples (Bantala) & Maximum Chromium (VI) Tolerant Capacity- $(\mathrm{mg} / \mathrm{ml})$ \\
\hline $\mathrm{S} 1$ & 0.3 \\
$\mathrm{~S} 2$ & 0.3 \\
$\mathrm{~S} 3$ & 0.3 \\
$\mathrm{~S} 4$ & 0.3 \\
$\mathrm{~S} 5$ & 0.2 \\
$\mathrm{~S} 6$ & 0.3 \\
$\mathrm{~S} 7$ & 0.3 \\
$\mathrm{~S} 8$ & 1.8 \\
$\mathrm{~S} 9$ & 0.5 \\
$\mathrm{~S} 10$ & 0.5 \\
$\mathrm{~S} 11$ & 0.2 \\
$\mathrm{S12}$ & $\mathbf{2}$ \\
$\mathrm{S} 13$ & 0.3 \\
$\mathrm{~S} 14$ & 1.8 \\
$\mathrm{~S} 15$ & 1.8 \\
$\mathrm{~S} 16$ & 0.5 \\
\hline
\end{tabular}

Heavy metal tolerance index: Overall maximum $\mathrm{Cr}(\mathrm{VI})$ tolerant capacity at $2 \mathrm{mg} / \mathrm{ml}$ concentration was shown by the S12 isolate with a tolerance index value of 0.12 at the same concentration. While some isolates failed to survive at higher concentrations of $\mathrm{Cr}$ (VI) used, others thrived and displayed variable metal tolerance index with time. It was observed that as time progressed, the values of the index increased with maximum being at the last $\left(14^{\text {th }}\right)$ day of observation. A comparison of the maximum metal tolerance index values by the various fungal isolates against exposure to different concentrations of hexavalent chromium is provided (see Figs. 3 - 6). It was seen that all the fungal isolates S1 - S4 in Fig. 3 had same trends of maximum tolerance index with maximum value of 1 and managed to survive upto $0.5 \mathrm{mg} / \mathrm{ml}$ concentration of $\mathrm{Cr}$ (VI), while among S5 - S8 in Fig. 4, S5 was sensitive above concentration of $0.2 \mathrm{mg} / \mathrm{ml} \mathrm{Cr}$ (VI) with maximum Ti value of 1 , followed by $\mathrm{S} 6$ and $\mathrm{S} 7$ at $0.3 \mathrm{mg} / \mathrm{ml}$ having $\mathrm{Ti}$ values 0.65 and 0.6 respectively and both having maximum $\mathrm{Ti}$ value of 1 at $0.2 \mathrm{mg} / \mathrm{ml}$ concentration respectively and S8 had a very high tolerance capacity of $1.8 \mathrm{mg} / \mathrm{ml}$ with $\mathrm{Ti}$ value of 0.075 with maximum $\mathrm{Ti}$ value of 1 at $0.1 \mathrm{mg} / \mathrm{ml}$ concentration. The fungal isolate $\mathrm{S} 11$ (see Fig. 5) was able to survive only upto 0.2 $\mathrm{mg} / \mathrm{ml}$ of $\mathrm{Cr}(\mathrm{VI})$, with maximum Ti value of 1 whereas S9 and $\mathrm{S} 10$ survived upto $0.5 \mathrm{mg} / \mathrm{ml}$ 
concentration with Ti values of 1 and 0.82 and maximum Ti value of 1 at 0.5 and $0.3 \mathrm{mg} / \mathrm{ml}$ concentration respectively and $\mathrm{S} 12$ with maximum Ti value of 1 at $0.5 \mathrm{mg} / \mathrm{ml}$ concentration and $\mathrm{Ti}$ value of 0.12 , surviving at overall highest concentration of $2 \mathrm{mg} / \mathrm{ml}$; while $\mathrm{S} 13$ (see Fig. 6) survived only upto $0.3 \mathrm{mg} / \mathrm{ml}$ concentration of $\mathrm{Cr}(\mathrm{VI})$ with Ti value of 0.31 and maximum $\mathrm{Ti}$ value of 1 at $0.2 \mathrm{mg} / \mathrm{ml}$ concentration, followed by $\mathrm{S} 16$ at $0.5 \mathrm{mg} / \mathrm{ml}$ concentration with maximum Ti value of 1 and finally $\mathrm{S} 14$ and $\mathrm{S} 15$ survived upto $1.8 \mathrm{mg} / \mathrm{ml}$ concentration, each with $\mathrm{Ti}$ value of 0.062 and maximum Ti value of 1 at 0.3 and $0.5 \mathrm{mg} / \mathrm{ml}$ concentration respectively.
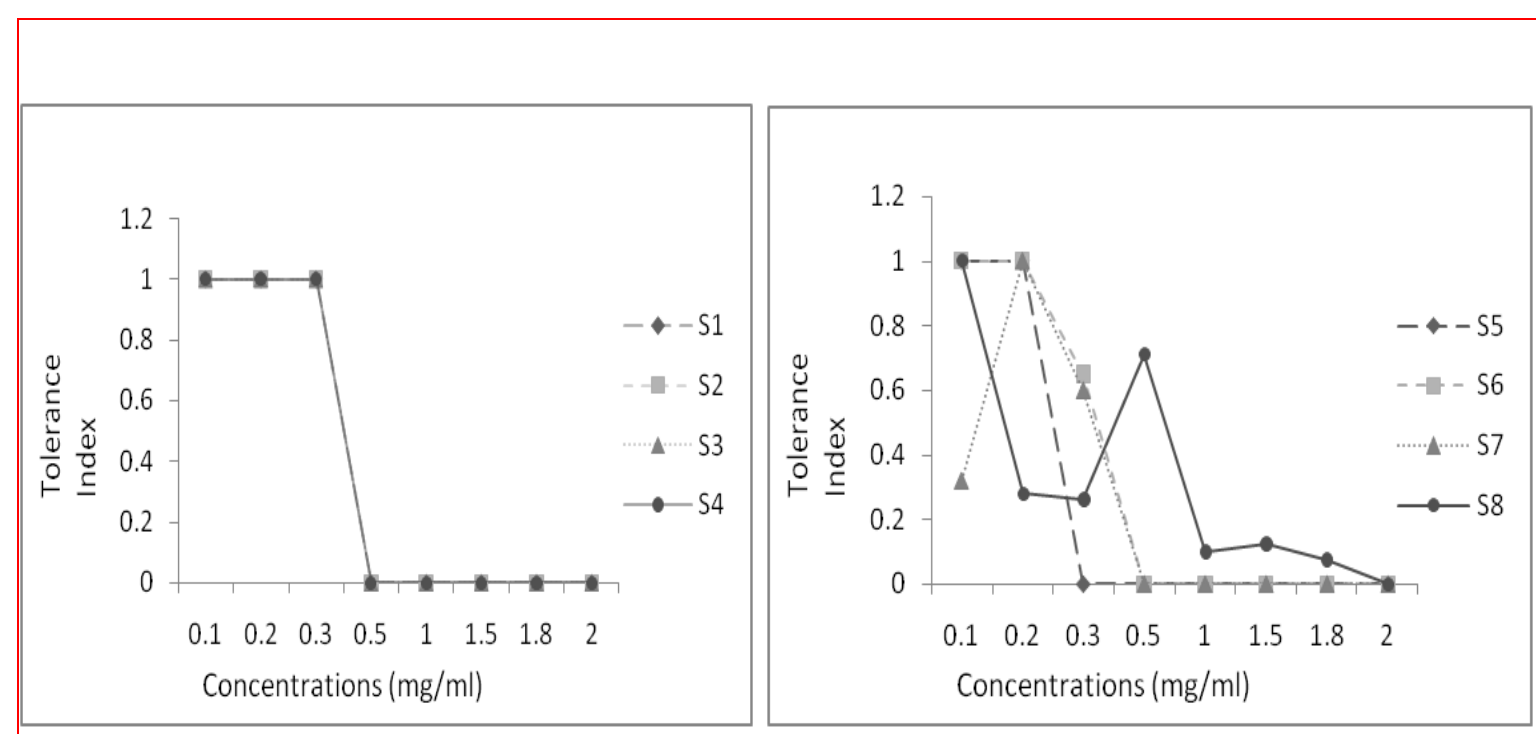

Figure 3. Comparisons of maximum

Figure 4. Comparisons of maximum tolerance

tolerance index among isolates S1 - S4 index among isolates S5 - S8
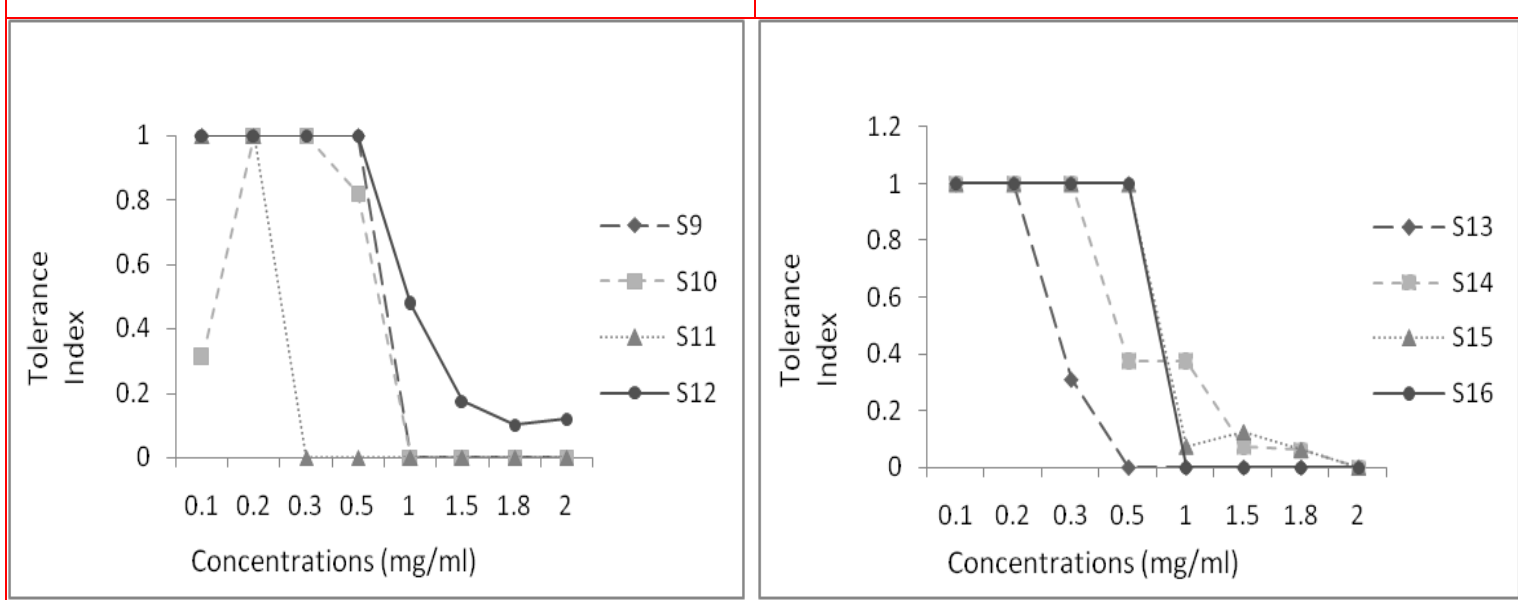

Figure 5. Comparisons of maximum tolerance index among isolates S9 - S12

Figure 6. Comparisons of maximum tolerance index among isolates S13-S16 


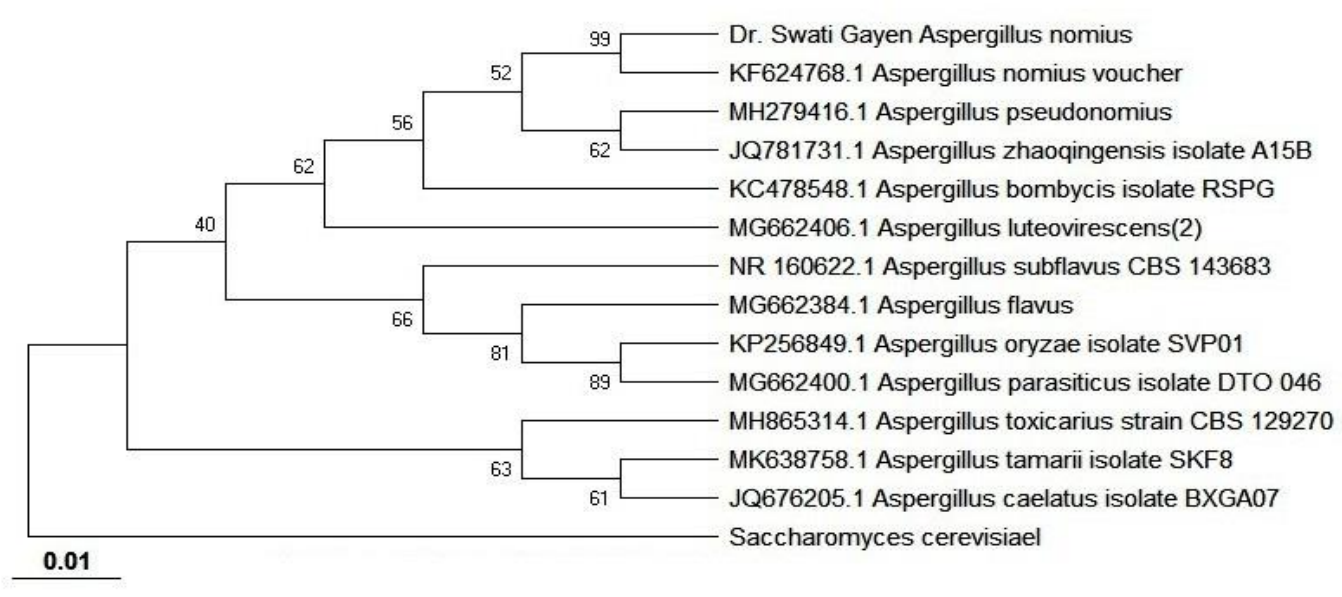

Phylogentic Tree of the Strain Dr. Swati Gayen

Figure 7. Fungal ITS sequencing analysis and phylogeny.

Fungal ITS sequencing analysis and phylogeny: In our current progress of study we were successful in isolating a fungal strain (S12) with a maximum $\mathrm{Cr}$ (VI) tolerant ability at $2 \mathrm{mg} / \mathrm{ml}$ from Kolkata Leather Complex tannery area. Fungal ITS region sequencing and analysis done by MTCC, CSIR-IMTECH revealed that, the most $\mathrm{Cr}$ (VI) tolerant strain (S12) we are working with has $99.82 \%$ similarity with and is identified as an Aspergillus nomius strain (see Fig. 7).

As far our best knowledge, this is an exclusive study where it has been observed that an Aspergillus nomius strain is tolerant to hexavalent chromium as high as upto $2 \mathrm{mg} / \mathrm{ml}$ concentration, although there have been other studies on various Aspergillus strains including Aspergillus nomius where it has been seen to be tolerant to other heavy metals like Cu (II), $\mathrm{Ni}$ (II), Pb (II), Cd (II), As (II) etc. (Congeevaram et al. 2007, Oladipo et al. 2016, Chatterjee et al. 2019).

This study involves the isolation of hexavalent chromium tolerant fungal strains from KLC tannery effluent and derivation of the metal tolerance capacities in the form of their respective metal tolerance index. We conclude that, this data would be further used in our future studies where their biomass can be employed for the biosorption of hexavalent chromium.

As conclusions, all of the 16 fungal isolates were found to be chromium (VI) tolerant. Maximum chromium(VI) tolerance was displayed by the sample $\mathrm{S} 12$ at concentration $2 \mathrm{mg} / \mathrm{ml}$. The sample was identified as having $99.82 \%$ similarity with Aspergillus nomius strain. 


\section{ACKNOWLEDGEMENTS}

Authors wish to acknowledge their sincere thanks to the Department Of Science and Technology, Government Of West Bengal for the financial support in this research work.

\section{REFERENCES}

Ahn, C. K., Park D., Woo S. H. \& Park J. M. 2009. Removal of cationic heavy metal from aqueous solution by activated carbon impregnated with anionic surfactants. Journal of Hazardous Materials. 164: 1130-1136.

Akpor, O. B. and Muchiem M. 2010. Remediation of heavy metals in drinking water and wastewater treatment systems: Processes and applications. International Journal of the Physical Sciences. 5: 1807-1817.

Annual report 2009 - 2010. Commerce and industry department, Government of West Bengal, West Bengal Industrial Development Corporation. Industry Specific Review: Leather Industry, 70-72.

Brierley, J. A. 1990. Production and application of Bacillus-based product for use in metals biosorption. In : Volesky B. (ed) Biosorption of Heavy Metals. CRC Press, Boca Raton, FL, pp. 305-312.

Chatterjee, A, Das, R. and Abraham, J. 2019. Bioleaching of heavy metals from spent batteries using Aspergillus nomius JAMK1. International Journal of Environmental Science and Technology.

Congeevaram, S., Dhanarani, S., Park, J., Dexilin, M. \& Thamaraiselvi, K. 2007. Biosorption of chromium and nickel by heavy metal resistant fungal and bacterial isolates. Journal of Hazardous Materials. 146(1-2): 270-277

Das, M. 2008. Leather complex turns threat to environment. The Indian Express.

Das, S.K., Singha, B., Naiya, T.K. and Bhattacharya, A.K. 2011. Cr(VI) Ions Removal from Aqueous Solutions Using Natural Adsorbents-FTIR Studies. Journal of Environmental Protection. 2: 729-735.

Gadd, O. M., White C. and de Rome L. 1988. Heavy Metal and Radionuclide Uptake by Fungi and Yeasts. In : Norris, P. R. and Kelly, D.P. (eds) Biohydrometallurgy, Proceedings of the International Symposium, Warwick 1987. Science and Technology Letters, Kew, Surrey, U.K., pp. 421-436.

Gupta, V.K. and Rastogi A. 2009. Biosorption of hexavalent chromium by raw and acid treated green alga Oedogonium hatei from aqueous solutions. Journal of Hazardous Materials. 163: 96-402.

Hutchinson, T.C. and Symington M.S. 1997. Persistence of metals stress in a forested ecosystem near Sudbury, 66 yrs after closure of the O'Donnell roast bed. Journal of Geochemical Exploration. 58: 323-330.

Magyarosy, A., Laidlaw R.D., Kilaas R., Echer C., Clark D.S. and Keasling J.D. 2002. Nickel accumulation and nickel oxalate precipitation by Aspergillus niger. Applied Microbiology 
and Biotechnology. 59 : 382-388.

Mishara, S. and Doble M. 2008. Novel chromium tolerant microorganisms: isolation, characterization and their biosorption capacity. Ecotoxicology and Environmental Safety. 71: 874-879.

Oladipo, O.G., Awotoye, O.O., Olayinka, A., Ezeokoli, O.T., Maboeta, M.S. and Bezuidenhout, C.C. 2016. Heavy metal tolerance potential of Aspergillus strains isolated from mining sites. Bioremediation Journal. 20(4): 287-297.

Papp, J.S. 1985. Chromium. In: Knoerr, A.W. (ed) Mineral facts and problems. Bureau of Mines Bulletin 675. U.S. Printing Office, Washington D.C.

Patrón-Prado, M. Acosta-Vargas B., Serviere-Zaragoza E. \& Méndez-Rodríguez L. 2010. Copper and Cadmium biosorption by dried seaweed Sargassum sinicola in saline wastewater. Water, Air and Soil Pollution. 210: 197-202.

Philip, L., Iyengar, L., \& Venkobachar, C. 1998. $\mathrm{Cr}(\mathrm{VI})$ Reduction by Bacillus coagulans Isolated from Contaminated Soils. Journal of Environmental Engineering. 124(12): 1165-1170.

Rajamani, S., Ramasami T., Langerwerf J.S.A., and Schappman J.E. 1995. Environmental management in tanneries-feasible chromium recovery and reuse system. Proceedings of the 3rd International Conference on Appropriate Waste Management Technologies for Developing Countries, AWMTDC 1995. Nagpur, India, pp. 965-969.

Ranjan, D., Srivastava P., Talat V. and Hasan S.H. 2009. Biosorption of Cr (VI) from water using biomass of Aeromonas hydrophila: central composite design for optimization of process variables. Applied Biochemical Biotechnology. 158: 524- 539.

Santhi, R. and Guru V. 2014. Biosorption of Hexavalent Chromium Using Aspergillus niger dead biomass and its optimization studies. International Journal of Current Microbiology and Applied Sciences. 3(10): 669-678.

Siddiquee, S., Rovina, K., \& Azad, S.A. 2015. Heavy Metal Contaminants Removal from Wastewater Using the Potential Filamentous Fungi Biomass: A Review. Journal of Microbial \& Biochemical Technology. 07: 06.

Volesky, B. 1987 Biosorbents for metal recovery. Trends in Biotechnology. 5: 96-100.

Volesky, B. and Naja G. 2007. Biosorption technology: starting up an enterprise. International Journal of Technology Transfer and Commercialization. 6: 196-211.

Received: 02th May 2019; Accepted: 17th February 2020; Published 07th January 2021. 